\title{
The Key Components Of Knowledge Transfer For Problem Solving In Adaptive Reuse Projects: A Qualitative Study
}

\author{
Kartina Alauddin ${ }^{1 . a}$, Mohd Fisal Ishak ${ }^{2}$, Mohammad Nasharudine Shuib ${ }^{3}$ and Halmi Zainol ${ }^{4}$ \\ 1,2,3,4 Faculty of Architecture Planning and Surveying, Universiti Teknologi MARA, Seri Iskandar Campus, Seri Iskandar, 32610, Perak, \\ Malaysia.
}

\begin{abstract}
The adaptive reuse project requires complete and accurate historical information and high levels of expertise from the project team members. Within the typology of adaptive reuse projects, the ability to capture and transfer the unique set of experience from project to project is important to create the relevant knowledge. Previous adaptive reuse studies focused on project success, potential for reuse, benefits, and sustainability. However, research related to creating and transferring skills and knowledge from adaptive reuse project settings has received relatively little attention to date. The study specifically investigates the key components of knowledge transfer for the problem solving process in adaptive reuse projects. In particular, the paper seeks to establish an intellectual capital framework for adaptive reuse projects that could help the project team members transfer their knowledge during problem solving process. This study adopted the qualitative approach to data collection. The data were collected from 14 semistructured in-depth interviews across two case studies. Data from the interviews were analyzed using content analysis for within-case analysis with the aid of Nvivo Version 9. The finding of the study highlights that the key factors of transferring knowledge were effectiveness and efficiency, similar project teams, project teams actions and sources of information on transferring of intellectual capital among project team members. The contribution of this study is the development of an intellectual capital framework for adaptive reuse projects. This framework can be used as a template for future practice and research in the field of adaptive reuse and knowledge management. In conclusion, the study enables the integration of intellectual capital and knowledge transfer theory within the specific contextual adaptive reuse project settings.
\end{abstract}

\section{Introduction}

Involvement in adaptive reuse projects is not an easy process. Project teams have to go through various stages or processes that are quite different from the construction of a new building. The nature of each construction projects is temporary and could contribute to loss of skill and knowledge. The challenge is to ensure that the richness of skill and knowledge in preservation practices are kept and well preserved. The skill and knowledge of the project team members are very valuable for the enhancement of problem solving capability in the next project. Therefore, managing the skill and knowledge gathered from a project is important to ensure that the knowledge and experience of the project teams are not lost for future adaptive reuse projects. In the process of redevelopment of old buildings, the adaptive reuse concept has been applied to ensure that the new building function is compatible with the old building historical evidence. This method involves the adaptation of the building which started with the acquisition and ended with the occupation of the building (Latham 2000). The uniqueness of adaptive reuse concept is that it often relates to heritage architectural significance of the building involved. The adaptive reuse projects often raise complexity in the design and construction process as compared to new building projects. This includes incomplete and inaccurate design information (Shipley, Utz \& Parson 2006; Karim et. al 2007) and lack of capable professional expertise (Ball 1999; Kurul 2007) that affect the design and construction process of this kind of project. Moreover, in the design and construction phases, availability of historical information, such as original drawings and documents related to the buildings are important in the design and construction process (Waleed, Yasser, Lobna and Ashraf, 2015). Hence, it is important for each practitioner in the adaptive reuse projects to understand and embrace the knowledge of heritage requirements in the problem solving process.

The research problem is concerned with the lack of research related to knowledge management in adaptive reuse projects. Previous studies have been defined individual and unrelated finding between adaptive reuse and knowledge management. Therefore, the knowledge management approach will be adopted as this study in regards to identifying the key components in problem solving within knowledge creation from project to project over time. This is critically important to be applied by the

\footnotetext{
${ }^{a}$ Corresponding author: karti540@perak.uitm.edu.my
} 
client, consultants and contractor. This study may produce a better approach within the combination of adaptive reuse and the knowledge management process around the project teams' skills.

\section{Intellectual Capital and Knowledge Transfer}

The main problem in construction projects is the difficulty to accumulate knowledge. According to Kululanga and McCaffer (1993) the greatest challenge in construction projects is the difficulty in managing intellectual capital of project team members. Based on the explicit-tacit and individual-social dimensions of intellectual capital, four types of knowledge have been identified from organisational context: conscious knowledge, automatic knowledge, objective knowledge and collective knowledge (Spender 1996). Spender's model which considers conscious knowledge is formal, facts or conceptual knowledge, and is reliant on the individual's conceptual skills and intellectual abilities. Automatic knowledge is similar with experiential knowledge terms. This type of knowledge is practicaloriented where the individual takes an action based on individual conceptual knowledge which is developed from practical experience. Objective knowledge is also regarded as a shared body of professional knowledge that has been documented and stored in writing, drawings, procedures, regulations and contracts. Collective knowledge is similar to embedded social knowledge or organisational routines and shared norms in any process involved. Through intellectual capital, it would be proven that the experiences of individuals and project throughout the process are of utmost importance and crucial to the success of project. Figure 1 shows the integration of knowledge transfer and intellectual capital components for problems solving in adaptive reuse projects.

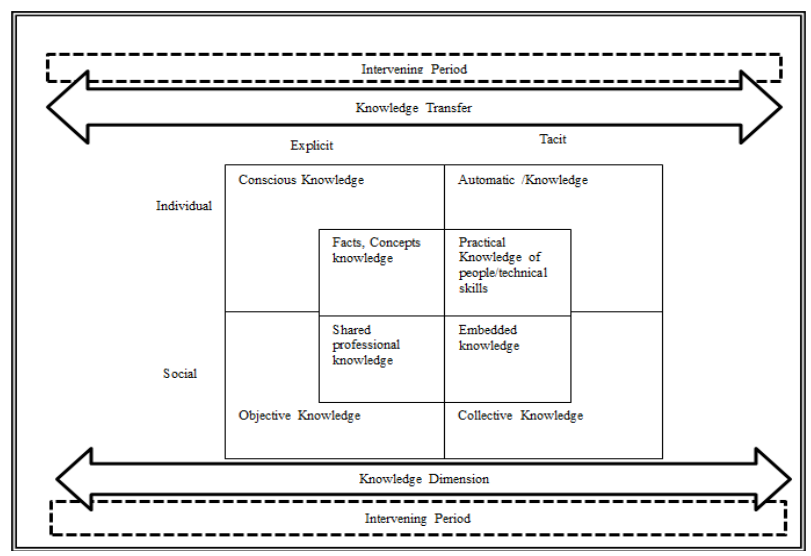

Figure 1. Knowledge transfer and intellectual capital components for problems solving

\subsection{Knowledge Transfer}

Knowledge transfer has been defined as another factor that affects the knowledge transfer approach when similar client and project teams collaborate again for another project after certain time gaps for each project. After a certain time gaps and considering what might be lost in a relationship to one project, electronic media was considered the best approach to start transferring the information and knowledge before face-to-face contact takes place when the project starts (Petra and Lars-Henrik 2014). It is crucial for knowledge transfer among project teams' members from the completed earlier project for there to be 'brainstorming' activities and a transfer to future projects to get better results in terms of project success (Maqsood 2006). Perhaps, this is necessary to combine soft and hard knowledge (Sajjad 2008) in the 'community of practice' approach to ensure that the management of accumulative intellectual capital from the earlier project for the future project is in good hands. The significance of knowledge transfer and a sharing approach in managing the intellectual capital particularly in the construction sector is appropriate to what Sajjad pointed to in his study.

\subsection{Knowledge Dimension}

There are two dimensions of knowledge; tacit and explicit. The tacit dimension refers to action, experience and involvement in any situation or circumstances. Tacit knowledge is comprised of both cognitive and technical components (Nonaka, 1994; Nonaka and Krogh, 2009). The cognitive components are related to mental maps, beliefs, paradigms and viewpoints of the individual in any organization or circumstances. In terms of the technical components, they are related to the skills, the expertise and the application of the know-how process, which are more related to this research. The explicit dimension is easily reduced as writing. Frequently explicit dimension takes the forms of documents, drawings, reports, historical information, heritage abstract etc. Both knowledge dimension; tacit and explicit information are critical in the problem solving process in adaptive reuse. The level of knowledge transfer includes the project teams transferring the project between project teams and across project teams. It also involves knowledge transfer happening between projects and across projects over time. In this study, this is considered as the intervening period.

\subsection{Intellectual Capital and Knowledge Transfer in Adaptive Reuse}

Adaptive reuse is defined as a process of transforming the functions, the structures and the fabric of old buildings to contemporary ways in the design and construction process. The process is complex and needs to be managed with the appropriate management skill of multi project team members who collaborate with the historic and modern value of the design and construction components (Alauddin, 2014). In terms of intellectual capital, it is more complicated and difficult to manage and ensure it can be used and that there is an improvement when the project teams jump from project to project. The process of transferring and managing the intellectual capital among multidisciplinary team members with different 
expertises and knowledge needs to be investigated since there is a lack of research on the specifics of complex projects such as adaptive reuse projects. Most previous studies focused on the content of knowledge either tacit or explicit knowledge in general construction, procurement projects and specifically on a key person but not on the entire process (Yuan and Yang 2009; Kivrak et al. 2008). This is an important first step in developing a platform for the study proposed in this research. It is acknowledged that knowledge should be captured from one project to the next but it is important to understand the process of achieving this. In reality, adaptive reuse projects can take years to come to fruition and are not common. The intervening years between projects represent a time where knowledge can be captured, enhanced, transformed, developed and then transferred to the next project. Investigating and analyzing sequential adaptive reuse projects located as events in an intervening period such as this would provide an invaluable case study and contribute to the body of knowledge in this field.

\section{Research Methodology}

To further develop and investigate the key components in knowledge transfer within the adaptive reuse scope, a qualitative research study was carried out. The research method is illustrated in Figure 2.

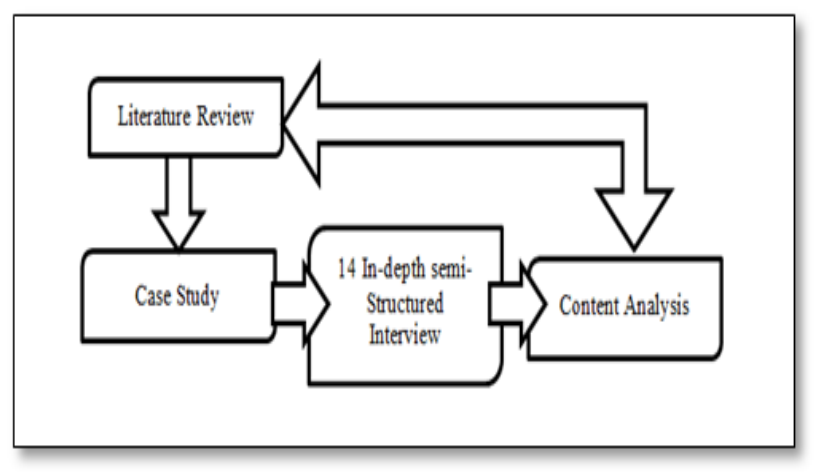

Figure 2. Research Methodology

The study begins with a thorough literature review. Two areas of literature are reviewed precisely to support the development of the research question, adaptive reuse literature and knowledge management literature. The rationale of these literature areas is explained in Table 1.

Table 1. The rationale for literature selection.

\begin{tabular}{|l|l|}
\hline \multicolumn{1}{|c|}{ Adaptive reuse literature } & Knowledge Management literature \\
\hline $\begin{array}{l}\text { Identification of adaptive } \\
\text { reuse issues or context that is } \\
\text { focused by previous studies } \\
\text { on the adaptive reuse } \\
\text { environment. }\end{array}$ & $\begin{array}{l}\text { This literature is used to support } \\
\text { the development of a conceptual } \\
\text { model for this research. It relates to } \\
\text { the knowledge transfer and the } \\
\text { intellectual capital particularly in a } \\
\text { temporary construction } \\
\text { organisation. }\end{array}$ \\
\hline
\end{tabular}

This study undertakes that the previous adaptive reuse studies are lacking in injecting knowledge management into their research outcomes. The empirical study on adaptive reuse projects related with knowledge transfer and intellectual capital particularly in relation with the problem solving process is needed to developthe bridge for the gaps. Therefore, the research question in this study is "What are the key components knowledge transfer that contribute to problems solving on adaptive reuse projects within the intervening period?". This study generalizes the theoretical propositions and does not enumerate frequencies in analysing and discussing data collection from interviews and documents. Yin (2009) restated the definition of case study technicality as an empirical inquiry that investigates a contemporary event in depth and within its real-life context, when the boundaries between event and context are not clearly evident. Table 2 reveals the links of this study to relate basic questions, which show the methods of data collection and the respondents involved in qualitative interviews.

Table 2. Coordination of data collection method with research question.

\begin{tabular}{|c|c|c|c|c|c|c|c|c|c|}
\hline \multicolumn{2}{|c|}{ Methods } & \multicolumn{2}{|c|}{ WHAT } & \multicolumn{3}{|c|}{ WHO } & \multicolumn{3}{|c|}{ HOW } \\
\hline 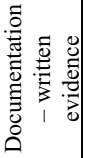 & 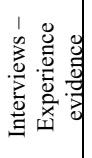 & 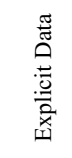 & 营 & 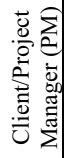 & 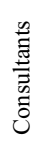 & 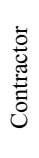 & 胥 & 常 & 第 \\
\hline Yes & Yes & $\begin{array}{l}\text { Any } \\
\text { recor } \\
\text { ds as } \\
\text { writt } \\
\text { en } \\
\text { evide } \\
\text { nce }\end{array}$ & $\begin{array}{l}\text { Intervi } \\
\text { ews to } \\
\text { obtain } \\
\text { unwritt } \\
\text { en } \\
\text { eviden } \\
\text { ce }\end{array}$ & \multicolumn{3}{|c|}{$\begin{array}{l}\text { Involvement, } \\
\text { Experience, } \\
\text { Knowledge } \\
\text { Skill, Expertise }\end{array}$} & \multicolumn{3}{|c|}{$\begin{array}{l}\text { In-depth } \\
\text { Interview } \\
\text { Face to face with } \\
\text { semi-structured } \\
\text { interview } \\
\text { schedule }\end{array}$} \\
\hline
\end{tabular}

This study has three logical reasons and rationales in using qualitative interviewing that have been adopted from Mason (1996). First, this study uses qualitative interviewing consists of semi-structured interviews. The semi-structured list of questions is based on preliminary thematic questions or parts, which contributed to the identification of the key components transferring the knowledge of client and project teams in the intervening period. Second, the ontological position is involved with the client and project teams' knowledge, views, understanding and experiences which are meaningful properties in exploring the key points for problem solving in reality. Third are the epistemological reasons for conducting interviews. Within-case analysis approach is adopted to analyse the qualitative interview data based on content analysis. This study adopts content analysis to theme and codes the interview transcriptions with the aid of qualitative analysis software, Nvivo 9. This involves storing the interview transcriptions from a total of 14 participants from two cases (Table 3). Before theming and coding the data, all the transcriptions will be read through to understand the whole situation and provide the specific key themes that are relevant to the research question. All the transcribed interviews are imported to 
the NVIVO as the 'sources' and have been named according to their position in both projects.

Table 3. Number of Participants

\begin{tabular}{|l|l|c|c|}
\hline \multicolumn{2}{|l|}{ Respondents Roles } & Case Study 1 & Case Study 2 \\
\hline 1 & Project Manager 1 & 1 & 1 \\
\hline 2 & Project Manager 2 & 1 & 1 \\
\hline 3 & Architect & 1 & 1 \\
\hline 4 & Building Surveyor & & 1 \\
\hline 5 & Fire Engineer & 1 & \\
\hline 6 & Quantity Surveyor & 1 & \\
\hline 7 & Town Planner & 1 & \\
\hline 8 & Heritage Advisor & 1 & \\
\hline 9 & Contractor & 1 & 1 \\
\hline 10 & $\begin{array}{l}\text { Structural } \\
\text { Engineer }\end{array}$ & & \\
\hline
\end{tabular}

\section{Contents Analysis Findings}

Data from interviews were transcribed from the audiotaped version to the written version with MS Word 2010. To ensure that the transcribed interview data were valid, the researcher repeated the process by listening for the second time while reading and checking with the first draft of the transcription. After the process of data validation, the interview transcripts were exported into Nvivo 9 for open coding processes. Each sentence from fourteen interview transcripts was read carefully to capture the essence of that sentence that would be used later in open coding. Open coding in Nvivo 9 involved collecting all the interview transcripts and grouping them into open themes where the researcher used a conceptual model with analytic and descriptive coding methods as a guide to identify the related themes. The analytic coding was started by assigning codes to possible variables, a process which integrated the literature review findings with the conceptual model. Descriptive coding assigned demographic characteristics to each participant by describing their different perceptions about the variables of the critical factors that contributed to adaptive reuse and knowledge transfer activities.

\subsection{Key Component 1: Efficiency and Effectiveness Mode}

This section analyses the project team members' point of views about the efficiency and the effectiveness in solving problems in case studies. The evidence from the interviews shows that the problems could not be solved quickly or easily due to the complexity of adaptive reuse projects. Particularly for the consultants, their experience showed that solving the problems required more time and was difficult because the design process was too long, the preparation of the fire engineering analysis required a sophisticated process and the amount of repetition involved in testing the load and strength of existing materials was high. Nevertheless, the contractor and the town planner had dissimilar views to the point just made. Their experiences indicated that problems had been solved more quickly and easily because the components of collaboration and the skills of other project team members provided reasons for this to happen.

Table 4. Evidence of effectiveness and efficiency of problemsolving process in case studies

\begin{tabular}{|l|l|}
\hline $\begin{array}{l}\text { Project } \\
\text { Meam }\end{array}$ & \multicolumn{1}{|c|}{ Quicker and Easier (Positive Views) } \\
\hline Contractor & $\begin{array}{l}\text { "..the structural engineer play the work well. } \\
\text { That would help because I can walk and resolved } \\
\text { problem stand there what to do and resolved on } \\
\text { the spot when working out together. Probably } \\
\text { working together being little bits better and at the } \\
\text { end of the day you will presence what client } \\
\text { going to disclosed." }\end{array}$ \\
\hline $\begin{array}{l}\text { Town } \\
\text { Planner }\end{array}$ & $\begin{array}{l}\text { "Because I am only dealing with the conceptual } \\
\text { side of things, problems was resolved really } \\
\text { quickly. Architect is fantastic architect done his } \\
\text { thought through a lot of issues..." }\end{array}$ \\
\hline $\begin{array}{l}\text { Quantity } \\
\text { Surveyor }\end{array}$ & $\begin{array}{l}\text { Obviously, it probably takes a longer time to } \\
\text { there were a lot of ideas which increased from } \\
\text { [the conventional]. So, it was more difficult than } \\
\text { a new building and more difficult than a general } \\
\text { refurbishment." }\end{array}$ \\
\hline $\begin{array}{l}\text { Fire } \\
\text { Engineer }\end{array}$ & $\begin{array}{l}\text { "The building approval took a month to gather } \\
\text { the approval from the fire brigade because we } \\
\text { were doing more detailed analysis. The fire } \\
\text { brigade and building surveyor's office came up } \\
\text { with more detailed questions." }\end{array}$ \\
\hline $\begin{array}{l}\text { Project } \\
\text { Manager the length of that process because they were } \\
\text { looking at from the design perspective, they were } \\
\text { trying to maximise the number of actual floors } \\
\text { within the building ... So, it took a long, long time } \\
\text { and a lot of probably stressful nights for the } \\
\text { structural engineer,..." }\end{array}$ \\
\hline
\end{tabular}

\subsection{Key Component 2: The Same Project Team}

The similar perspective between project manager 1 and project manager 2 regarding having the same teams in the projects definitely provided the evidence that these appointments benefited the client and the project. As the project manager who had significant experience on site, project manager 2 considered that it was more important to work together again with the same key people in project teams. The key important people with whom it was critical to work again in the sequence project were the architect, building surveyor and fire engineer. This was because the design parameters in adaptive reuse projects were dictated by fire engineering and building surveying requirements. The interaction between the architect, building surveyor and fire engineer led to innovative solutions which were acceptable from the 
client's point of view. Table 5 shows evidence of the project team's perceptions about how having the same team for the projects helped them in the problem-solving process. There were two categories of perceptions; positive and neutral. Positive perceptions demonstrated that the project team members had positive experiences in working with the same project team members in both projects. The same team members provided benefits in terms of more effective communication and greater understanding of the problems which made the problemsolving process more efficient. A neutral perception referred to project team members who accepted both situations either working with the same or in a different project team. This study identified that the contractor and heritage advisor were unaffected by the appointment of the same project team members.

Table 5. Evidence of having the same project teams in problemsolving process in case studies

\begin{tabular}{|c|c|}
\hline $\begin{array}{l}\text { Project } \\
\text { Team } \\
\text { Members }\end{array}$ & The Same Team \\
\hline $\begin{array}{l}\text { Quantity } \\
\text { surveyor }\end{array}$ & $\begin{array}{l}\text { "Yes, the same architect and the same builder. It } \\
\text { certainly helped ... if you work with a particular } \\
\text { consultant, even a particular architect, you get to } \\
\text { know how they work and get to know the things } \\
\text { they like to design including the buildings, the } \\
\text { way they go about things." }\end{array}$ \\
\hline Architect & $\begin{array}{l}\text { "Well, we had the same building surveyor...The } \\
\text { building didn't comply with building regulations } \\
\text { because it was not a new construction ... it was } \\
\text { because the existing building had heritage value } \\
\text { and the client wanted to keep that building } \\
\text { character..." }\end{array}$ \\
\hline $\begin{array}{l}\text { Building } \\
\text { Surveyor }\end{array}$ & $\begin{array}{l}\text { "I suppose the work of changing the consultant } \\
\text { when the work changed would be a little bit } \\
\text { difficult but with the same consultant, people } \\
\text { knew where you were heading. The difference } \\
\text { being that the approach was quite different." }\end{array}$ \\
\hline $\begin{array}{l}\text { Fire } \\
\text { Engineer }\end{array}$ & $\begin{array}{l}\text { "Not just the same company but the same } \\
\text { individuals which was very rare over that long a } \\
\text { period. Having the same individuals was very } \\
\text { helpful ... we learnt something along the way." }\end{array}$ \\
\hline $\begin{array}{l}\text { Project } \\
\text { Manager } \\
1\end{array}$ & $\begin{array}{l}\text { "I think it particularly helped. It helped because } \\
\text { they were all certainly the consultant team } \\
\text { because they knew exactly why certain things } \\
\text { were being done in the building and why they } \\
\text { couldn't do certain things." }\end{array}$ \\
\hline $\begin{array}{l}\text { Project } \\
\text { Manager } \\
2\end{array}$ & $\begin{array}{l}\text { "Definitely helped. We didn't have totally the } \\
\text { same team but really the key people were all the } \\
\text { same people. The architect was the same, the } \\
\text { building surveyor was the same, and the fire } \\
\text { engineer was the same ... And so, with the } \\
\text { interaction between the architect, the building } \\
\text { surveyor and, the fire engineer, they would come } \\
\text { up with those solutions that would be acceptable } \\
\text {...." }\end{array}$ \\
\hline $\begin{array}{l}\text { Town } \\
\text { Planner }\end{array}$ & $\begin{array}{l}\text { "This was probably a larger one than what I had } \\
\text { dealt with in my time as a town planner up to that } \\
\text { point, so, not everyone had an architect as } \\
\text { experienced as person who I dealt with ... That is } \\
\text { the way the legislation works." }\end{array}$ \\
\hline Contractor & $\begin{array}{l}\text { "It was dynamic. Knowing the team was OK. I } \\
\text { did not have any problem with new consultants } \\
\text { coming to join the team... What is most important } \\
\text { is them getting the job done with whatever is the }\end{array}$ \\
\hline
\end{tabular}

\begin{tabular}{|l|l|}
\hline & best result." \\
\hline Heritage & $\begin{array}{l}\text { "I don't have any influence that gets the job or do } \\
\text { anything like that.... One other thing was that I } \\
\text { was admiring the work of architect's firm as they } \\
\text { have results on the board..." }\end{array}$ \\
\hline
\end{tabular}

\subsection{Key Component 3: Project Team's Actions}

The building surveyor and contractor mentioned their own actions rather than that of other project team members. However, the client was more specific and related it to this research where they employed and used the same architect to again do the design and lead the project.This was considered appropriate with what this study had developed and contributed to new knowledge. This study carried out data analysis about the project team members' actions in solving problems according to their own disciplines and skills. There were project team members who referred to their own skills in describing the actions they took to address any challenges that they were facing. However, some project team members described other project team members' actions when discussing their perceptions about the problem-solving process. Table 6 shows evidence of the project team members' perceptions about the key component of action in the problem-solving process for case studies.

Table 6. Evidence for the key of action in the problem-solving process in case studies

\begin{tabular}{|c|c|}
\hline $\begin{array}{l}\text { Project } \\
\text { Team } \\
\text { Members }\end{array}$ & Key of Action \\
\hline $\begin{array}{l}\text { Building } \\
\text { Surveyor }\end{array}$ & $\begin{array}{l}\text { "...we didn't have the fire engineering in those } \\
\text { days. So we have to go to what we call the } \\
\text { building referees board.. So we prepared the } \\
\text { packages of modification applications to modify } \\
\text { the regulation to suit that recycling case." }\end{array}$ \\
\hline Contractor & $\begin{array}{l}\text { "Working together and the expertise and I think } \\
\text { it important always to give the young one to go } \\
\text { into the world and always sharp and it still a lot } \\
\text { of administration. And also important is the } \\
\text { whole culture things for working around. " }\end{array}$ \\
\hline Architect & $\begin{array}{l}\text { "I still had the ongoing discussion and working } \\
\text { with the property services as their client contact } \\
\text { and then we would go back through the various } \\
\text { groups to solve their problems ... so, I was } \\
\text { answering the question on site, inspecting the } \\
\text { works, sorting out the problems, writing the site } \\
\text { instructions to the contractor...as architects we } \\
\text { had to understand the building regulations and } \\
\text { how big the fire compartment that we can have } \\
\text { so we worked with building surveyor..." }\end{array}$ \\
\hline $\begin{array}{l}\text { Fire } \\
\text { Engineer }\end{array}$ & $\begin{array}{l}\text { "... architect recommended us because he want } \\
\text { build the people that the team know each other. } \\
\text { So it thinks that one the key roles for an architect } \\
\text { to a project manager to make sure you pick the } \\
\text { right team." }\end{array}$ \\
\hline $\begin{array}{l}\text { Quantity } \\
\text { Surveyor }\end{array}$ & $\begin{array}{l}\text { "...basically we were involve in consultant thing } \\
\text { to discuss broadly about the methodology how it } \\
\text { might occur and that the floor to be moved by } \\
\text { bay ... to make out the quantity or the quantum } \\
\text { of work you can talk to the construction manager } \\
\text { try to work out how might be done." }\end{array}$ \\
\hline Project & "... we saved the builidngs and parts of that had \\
\hline
\end{tabular}




\begin{tabular}{|l|l|}
\hline $\begin{array}{l}\text { Manager } \\
1\end{array}$ & $\begin{array}{l}\text { to obviously then be negotiated with the Council } \\
\text { and the heritage overlay to make sure we didn't } \\
\text { lose the integrity of the building." }\end{array}$ \\
\hline
\end{tabular}

\subsection{Key Component 4: Sources of Information}

This section describes the sources of information that help project teams to develop solutions. The sources of information refer to the explicit information sources or written documentation. This study has identified five main sources of information that were referred to in case study 1 by the client and project team members, which were related to adaptive reuse projects. The sources of information are shown in Figure 3. The five main sources were cost information, heritage information; fire engineering information, regulation information and additional information from content analysis of the interview data from 14 participants' background.

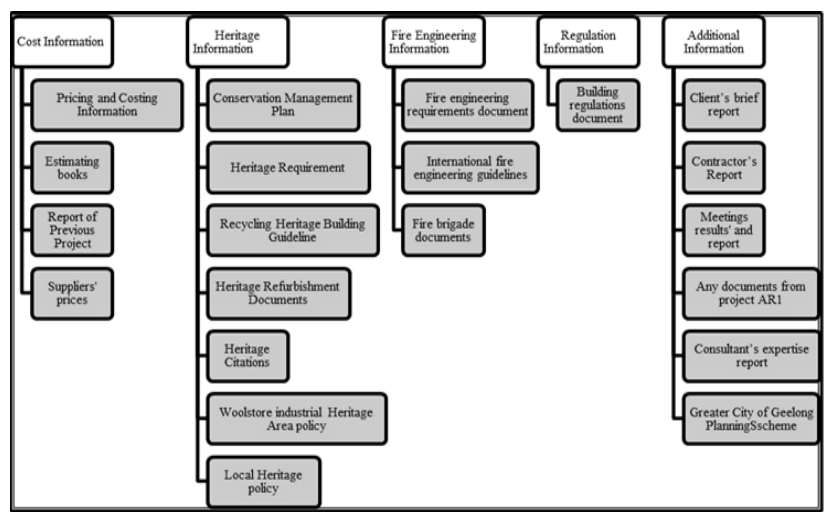

Figure 3. Sources of information in case studies

Table 7 shows evidence of the sources of information that were used and applied by project team members in case studies. The data findings demonstrated the sources of information used in case studies as the entire information that was appropriate in the within-case analysis.

Table 7. Evidence of sources of information referred to by project team members in the problem solving process for case studies.

\begin{tabular}{|l|l|}
\hline $\begin{array}{l}\text { Project } \\
\text { Meam } \\
\text { Members }\end{array}$ & \multicolumn{1}{|c|}{ Sources of Information } \\
\hline $\begin{array}{l}\text { Surveytity } \\
\text { "We have pricing information in our office that } \\
\text { comes from a few forms that you can get. You } \\
\text { can buy books that told you how much this thing } \\
\text { is worst. We have other costing information from } \\
\text { job that priced previously and information supply } \\
\text { prices that things that we gathering and } \\
\text { collecting in our normal daily work.." }\end{array}$ \\
\hline $\begin{array}{l}\text { Building } \\
\text { Surveyor }\end{array}$ & $\begin{array}{l}\text { ‥the called as recycle guideline and that } \\
\text { and Industrial Research Organisation] and also } \\
\text { ‥ The type of information on the first one there } \\
\text { was a lot of that with the information are } \\
\text { available. " }\end{array}$ \\
\hline Contractor & $\begin{array}{l}\text { "Absolutely I will prepare for the meeting, get } \\
\text { the answer for the consequences at the night } \\
\text { before and get the result in the meeting when } \\
\text { attended the meeting tomorrow, that's it....What }\end{array}$ \\
\hline
\end{tabular}

\begin{tabular}{|l|l|}
\hline & $\begin{array}{l}\text { we called that brain storming session. But I think } \\
\text { is more important keep people raise the issue and } \\
\text { think about it and we get to resolve it" }\end{array}$ \\
\hline Fire & $\begin{array}{l}\text { Fire engineering needed hundreds of documents } \\
\text { that we refer to but, specifically for heritage } \\
\text { refurbishment, the organisation that wrote the } \\
\text { Building Code also wrote some guidelines for } \\
\text { recycling heritage buildings. So, those were the } \\
\text { two documents for the approval part of the } \\
\text { design process." }\end{array}$ \\
\hline $\begin{array}{l}\text { Heritage } \\
\text { Advisor }\end{array}$ & $\begin{array}{l}\text { "That is not my personal opinion in the guidance } \\
\text { advice about the heritage policy and the planning } \\
\text { scheme. So, those documents were used to guide } \\
\text { me in giving advice to the architect and to the } \\
\text { planner responsible for the permit." }\end{array}$ \\
\hline $\begin{array}{l}\text { Project } \\
\text { Manager }\end{array}$ & $\begin{array}{l}\text { "No, there was no structural table which showed } \\
\text { the strength and anything to do with the timber. } \\
\text { So that hadn't been tested: they actually did it as } \\
\text { part of fire engineering. ...there was NO } \\
\text { Australian Standard or anything about what and } \\
\text { how the material should react under certain } \\
\text { conditions." }\end{array}$ \\
\hline
\end{tabular}

\section{Development of Intellectual Capital Framework}

The project teams members' actions are carried out stepby-step to undertake adaptive reuse problem solving. The major actions are critical in and rely on individual and social skills related to how to modify the building to suit heritage requirements for the building permit application and the need to track the industrialization status and to understand the client's requirements in heritage situations. The project team members can take immediate action to solve the problems on site (day-to-day actions) when the solution does not affect the major costs or heritage regulations. This knowledge can be transferred among the project team members individually and becomes the social routine within the intervening period. This framework can also show the knowledge gained on how to be respectful to the culture and the heritage. With this framework, the project team members can always keep on track and record and allocate the problems to the appropriate discipline for them to be solved (Figure 4)

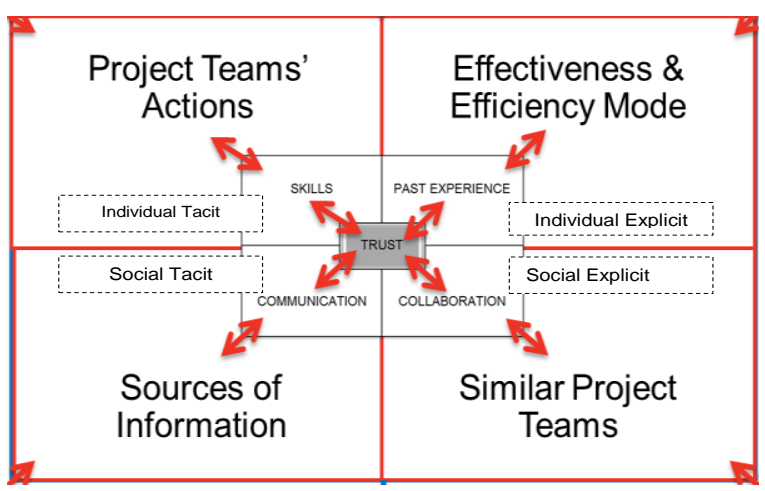

Figure 4. The Intellectual Capital Framework

\section{Conclusion}


The individual tacit and explicit knowledge attached to the history and the technical and management aspects accumulate to consolidate social tacit and explicit knowledge in the social routine to support the activities of knowledge transfer in adaptive reuse projects. This framework confirms London and Chen's (2004) theory that the component of intellectual capital is the accumulation of skills, experiences, competencies and knowledge of project teams. The present framework identifies the relationship and the reliance between the knowledge transfer and intellectual capital in the problem-solving process. It is difficult to link this finding to the previous literature, because little research has been published in this field. The lack of research on using knowledge management to support a whole series of research studies lead to this present framework's contribution being a new approach in the area of adaptive reuse research. Watson (2009) had identified that implementation project management tools and concepts as success factors in heritage projects, but the research was not empirically based. The complexity of adaptive reuse was mentioned in Kurul's (2007) and Latham's (2000) studies which involved the entire adaptive reuse process. This current study has expanded the meaning of complexity as involving the whole process but has contributed to the detail of the complexity in terms of problem solving, which was not covered by Kurul (2007); Kincaid (2000) or Latham (2000).

This framework demonstrated a new contribution to knowledge management in relation to adaptive reuse projects. Nonaka (1994) originally noted that knowledge management starts with knowledge creation, followed by knowledge transfer activity in common construction projects. However, this framework has also contributed to the concept by identifying that, in adaptive reuse projects within the intervening period, there is a reversal in the structure of knowledge management. The project teams in adaptive reuse projects in a time series scenario start with a richness in their knowledge about heritage requirements and regulations. The activity of knowledge transfer from the first project to the second project happens first, after which the project teams would create new skills and knowledge along with the development of new solutions for problems in future projects.

\section{References}

1. Alauddin, K., 'The Development of an Intellectual Capital Framework for Successful Adaptive Re-use', Sch.PCPM. Melbourne, RMIT University. PhD (2014)

2. Ball, R, 'Developers, regeneration and sustainability issues in the reuse of vacant industrial buildings', BRI, vol. 27, no. 3, pp. 140 -8 (1999).

3. Karim, SBA, Kamal, KS, Wahab, LA and Hanid, M, 'Risk assessment and refurbishment: The case of Ipoh Railway Station Perak, Malaysia', MICRA, Malaysia, March (2007)
4. Kincaid, D, 'Adaptability potentials for buildings and infrastructure in sustainable cities', Facilities, vol. 18, no. 3, pp. 155 -61(2000)

5. Kivrak, S, Arslan, G, Dikmen, I and Birgonul, MT, 'Capturing Knowledge in Construction Projects: Knowledge Platform for Contractors', JME, vol. 24, no. 2, pp. 87-95(2008)

6. Kululanga, G. and R. McCaffer, 'Measuring knowledge management for construction organizations', ECAM(5/6): 346-354.(1993).

7. Kurul, E 2007, 'A qualitative approach to exploring adaptive re-use processess', Facilities, vol. Vol. 25, no. No. 13/14, p. 16 (2007)

8. Latham, D, Creative re-use of buildings, 2 vols., (Donhead, Dorset 2000)

9. London, K and Chen, J 2004, 'Firm social, cultural and intellectual capital: strategic indicators of international client satisfaction', Int Conf., http://eprints.qut.edu.au/27358/ (2004)

10. Mason, J, 'Qualitative Researching', (SAGE Publication Inc., Great Britain. 1996)

11. Maqsood, T., 'The Role of Knowledge Management in Supporting Innovation and Learning in Construction', Sch.BIT. Melbourne, RMIT University. PhD: 181 (2006).

12. Nonaka, I. 'A dynamic theory of organizational knowledge creation', Organizational Science, 5(1), 14-37 (1994).

13. Nonaka, I., and von Krogh, G., 'Tacit Knowledge and Knowledge Conversion: Controversy and Advancement in Organizational Knowledge Creation Theory', Organization Science, 20(3), 635-652 (2009).

14. Petra M. Bosch-Sijtsema, Lars-Henrik Henriksson, Managing projects with distributed and embedded knowledge through interactions, Int. Journal of PM, Vol 32, Issue 8, 2014, Pages 1432-1444 (2014)

15. Sajjad, M. J., 'A holistic view of knowledge management strategy', Journal of Knowledge Management 12(2): 57-66 (2008).

16. Shipley, R, Utz, S and Parsons, M, 'Does adaptive reuse pay? A study of the bussiness of building renovation in Ontario, Canada', Int.Journal of HS, vol. Vol. 12, No. 6, p. 15 (2006)

17. Spender, J. C. 'Making knowledge the basis of a dynamic theory of the firm', Strategic Man. journal, 17, 45-62 (1996).

18. Yin, RK 'Case Study Research; Design and Methods', Fourth edn, vol. 5, (SAGE Publications, Inc, United States of America 2009).

19. Yuan, $\mathrm{M}$ and Yang, J, 'A Knowledge Management Framework to Promote Infrastructure Project Sustainability', in 15th Int.Symp on CME, Nanjing, China, vol. 29 (2009)

20. Waleed Tarek Ali Shehata, Yasser Moustafa, Lobna Sherif, Ashraf Botros ,"Towards the comprehensive and systematic assessment of the adaptive reuse of Islamic architectural heritage 
in Cairo", Journal of CHM\&SD, Vol. 5 Iss 1 pp. $14-29(2015)$

21. Watson, P 2009, 'A methodology for attaining and assessing project success for rehabilitation projects', Journal of BldgAppr, vol. Vol. 4, no. No.3, p. 9 (2009). 